\title{
THE BRNO ANATOMICAL WORKS ON MEAT CUTTING AND ON SKIN MORPHOLOGY
}

\author{
R. BÖHM ${ }^{1}$ and O. STĚRBA ${ }^{2}$ \\ ${ }^{1}$ Nejedlého 7, Brno - Lesná \\ ${ }^{2}$ Institute of Anatomy, Histology and Embryology, Faculty of Veterinary Medicine, \\ University of Veterinary and Pharmaceutical Sciences, 61242 Brno
}

Received September 22, 1994

Accepted March 30, 1995

\begin{abstract}
B ö h m R., O. S t e r b a : Brno Anatomical Works on Meat Cutting and on Skin Morphology. Acta vet. Brno 1995, 64: 9-12.

The present study deals with the period of cooperation between Prof. Dr. Jan Kolda and Doc. Dr. Jan Hökl and their pupils during which they elaborated standard methods of the cutting of meat based on anatomy. Another subject of cooperation were studies on the morphology of skin and hides under various methods of processing. The cooperation ended when first Doc. Hökl died prematurely and then Professor Kolda. The situation of that time prevented any of this kind of research to be continued.
\end{abstract}

Standards of meat cutting, morphology, skin, hides, Professor Kolda, Docent Hökl

An important part of the activities of Professor Dr. Jan Kolda and his colleagues after World War II was the implementation of anatomy in the technology of meat and raw materials of animal origin. We will draw attention to studies on the cutting of meat and on the histological structure of the skin of farm animals.

These subjects were suggested by Docent MVDr. et RNDr. Jan Hökl, a food expert (1907-1951), Head of the Department for Food Hygiene and Technology of the University of Veterinary Medicine in Brno in 1945-1951, situated in the same building as the Department of Anatomy. Jan Hökl left the university in 1938, after his habilitation thesis on studies of intestine hygiene and technology had been rejected. He found a good background in the Bata firm in Zlín, at first at their Biological Institute, later as head of the Municipal Institute for Food Research. His cooperation with professional workers in the area inspired him with many ideas for scientific and professional studies during the war and later.

At that time preparations were under way for the establishment of the Meat Research Institute. The most important person of these activities was MVDr. Alois Písa (1898 - 1978), an officer of the veterinary service of the army, who had worked during the war in the State Health Institute in Prague. The Meat Research Institute was established, naturally not until after the war, in 1947, as part of the Ministry of Nutrition. The main workplace was situated at Hökl's university department. From the very beginning the department had many concrete ideas for research activities, among them was the extensive work about animal foodstuffs which Hökl used to indicate as "Culinary Art". Jan Hökl applied many of his ideas in the dissertation theses of students of veterinary medicine.

He cooperated directly with Professor Kolda in issues connected with the cutting of meat because at that time efforts were done to standardize animal foodstuffs. The basis of this standardization could be nothing else but an accurate anatomical description of the cutting lines and the naming of the muscles, and/or bones, which the individual meat parts contained. Therefore, anatomy is the basis of cutting, the accompanying pictures are the same as pictures in anatomical books. Technologies include the proposed and used names of the parts of meat, their weights, culinary use and practical comments.

Work evidently began soon after 1945 because the first volume appeared in 1948. This was "The cutting of veal" by Jan Kolda and Jan Hökl, and under the title it was indicated as part of the research plan of nutrition No.19.07.07. This was probably the project of the Society 
for Research Activities in the Food Industry the representative of which at that time was again MVDr. Alois Piša. The research plan of this institute then had evidently been elaborated before 1948 and before the unification of the meat industry. The second book of its kind was "The cutting of pork" (1950) by the same authors; its lay- out and arrangement were the same.

The book "The cutting of beef" (1953) by Jan Kolda, Jan Hökl and Rudolf Böhm, linking up with the two previous books in terms of the content but not of the form, was published after the death of Jan Hökl. The authors of illustrations in the book are Professor Jan Kolda and his assistant Oldrich Sterrba. The arrangement was similar.

Little is now known about the six anatomical black-and-white wall tables published on the initiative of Jan Kolda and Rudolf Böhm and supported by the meat industry. The tables were drawn by Oldrich Sterrba and published by the Ministry of the Food Industry in 1953. They were drawings of larger parts (halves and quarters) of pork, veal and beef indicating the lines of cutting. They were used for instruction, in industry and trade. Later, the drawings found their way into textbooks and cookery books, they appeared also elsewhere and in this shape they have been preserved to the present day.

In 1954, Radim Najbrt and Miroslav Dobeš published a similar article "Contribution to the cutting of hare meat" which links up with one study of Hökl's student about hare meat as a foodstuff (Demela 1952). It refers to an unpublished study of Kolda and Hökl which is most probably the manuscript of the "Culinary Art", a work which had physically really existed in Hökl's inheritance. In 1958, Oldřich Stěrba and Rudolf Böhm published their article on the cutting of mutton, again linking up with the previous ones. A publication had later been prepared about the cutting of rabbit meat; however, it remained unfinished and the manuscript most probably does not exist any more.

Professor Jan Kolda had a very sympathetic relationship to applied anatomy, often touching this topic in various discussions and always discovering new memories of his youth and his own practical experiences. He was also very interested in the development of the book of Rudolf Böhm and Vladimír Pleva about the microscopy of meat. After his death this kind of anatomical research ceased to continue.

Another link between anatomy and the technology of raw materials of animal origin were studies about the morphology of skins of farm animals. Jan Hökl was sufficiently acquainted with the problems of hides as raw material for leather production at the Bata company in Zlín. During Hökl's life, during one of the few excursions, we visited the warehouses of skins and hides of the Bata company. At this occasion, and later at many other, Jan Hökl talked about the problems connected with skins and hides, among others, about hair vortices which change during the life of cattle and which could be a character distinguishing the hides of heifers from those of cows. His relationship to Professor Kubelka, the skin and hide expert and technologist from the Technical College in Brno, was well known.

Shortly after the war, Professor Kolda decided that the topic of some dissertation theses would be skins and hides. In 1948 Josef Rủžička defended his thesis on the histology of the skin of a kid, and Otakar Zeman on the skin of the dog; in 1950 Radim Najbrt on the fissility of horse hide, and Rudolf Böhm on the structure of the rabbit skin; in 1951 Vladimír Pleva on argyrophilic fibrils in the skin, and in 1953 Vladimír Geissel on fat and mucine in the skin. In 1956 Jan Sevela defended his thesis on the structure of the cattle corium. In the late 40 s, Alois Frank began research into the microscopical structure of the skin of horse, however, due to political reasons he was expelled from the university. He did not defend his thesis until 1959, ten years later, after he returned to the university and finished his studies. Professor Jan Kolda liked to deal with the anatomy of the skin and with dermal formations. MVDr. Frantǐ̌ek Mládek, his assistant, was his partner and collaborator during his work on lecture notes in dermatology in 1951. Professor Kolda himself evidently managed the laboratory work of the whole project of skin research, Mr. Votápek, his technician, elaborated 
a large amount of histological samples taken from fresh, salted or in other ways preserved skins and tanned hides. These samples were sent from Zlin. The whole conception, protocols and other documents have not been preserved. In the first half of the 50s, after Docent Hökl died, and Jan Kolda was alternating his activities at the institute with stays in hospitals and convalescent homes, there was nobody who would continue in this cooperation between the two institutes. The whole set of preparations was later destroyed.

It is interesting that approximately in the same post-war period, about twenty similarly projected dissertation theses on the histology of skins during technological processing were defended at the University of Veterinary Medicine in Vienna. Their short summaries were published in the periodical Wiener Tieräztliche Monatschrift between 1951 and 1953.

It is also worth mentioning that virtually at the same time, nine dissertation and diploma theses on the structure of hair and fur were elaborated at the Histological Institute of the University of Veterinary Medicine in Brno (i.e. Krechler 1951, Grieger 1953, Pospísil 1953, Roubal 1953, Holman 1956, Hrabák 1958, Těsíková 1961, Pejhovská 1962, Steinmetz 1962). These works, however, linked up with the tradition of the institute in the period between the two world wars (Professor MUDr. Karel Sulc); nevertheless, their conception was influenced by the changing technology of farm animal breeding. Novotný and Böhm (1963) drew attention to the specific aspects of veterinary morphology in terms of the hygiene and technology of meat and of raw materials of animal origin.

The period of close relationships between the institutes of veterinary morphology and veterinary hygiene and food technology in Brno in the period between 1945 and 1950 was marked by two great personalities, Professor Jan Kolda and Docent Jan Hökl, by the closeness of their intellectual and professional interests and localization of their workplaces. Mutual cooperation resulted in a completely. new concept of work on the cutting of meat and morphology of the skin of farm animals. The premature death of both personalities in the 50 s terminated this period. Later conditions never allowed this tradition to continue.

\section{Brněnské anatomické práce o dělení masa a morfologii kủže}

Sdělení zachycuje období spolupráce prof. Dr. Jana Koldy a doc. Dr. Jana Hökla a jejich žákủ při vypracovávání standardních způsobů dělení masa anatomicky podložených. Jiným tématem spolupráce byl výzkum morfologie kủže a usní při různých technologiích zpracování. Spolupráce v obou oblastech skončila předčasným úmrtím doc. Hökla a pak i prof. Koldy. Tehdejší poměry pak zabránily dalšímu výzkumu v těchto směrech.

\section{References}

BÖHM R. 1950: The structure of the skin of rabbit. (In Czech).Thesis VŠV Brno

BÖHM R.,- PLEVA V. 1956: Microscopy of the meat and animal raw materials. (In Czech). SNTL Praha, $176 \mathrm{p}$. DEMELA J. 1952: The hare as a food. I. (In Czech). Thesis VŠV Brno

FRANK A. 1959: The histological pattern of skin of the horse. (In Czech). Thesis VŠV Brno

GEISSEL, V.1953: Fat and mucine in the skin. (In Czech).Thesis VŠV Brno

GRIEGER C. 1953: Hairs of the hare. (In Czech). Thesis VŠV Brno

HOLMAN J. 1956: Bristles of the pig. (In Czech). Thesis VŠV Brno

HRABÁK R. 1958: Winter hairs of nutria. (In Czech). Thesis VŠV Brno

KOLDA J., HÖKL J. 1948: Cutting of veal. (In Czech). Tiskové podniky Ústř. svazu čs. průmyslu Praha, 54 p. KOLDA J., HÖKL J. 1950: Cutting of pork. (In Czech). Tiskové podniky- Průmyslová služba ÚSČP, Praha, 25 p. KOLDA J., HÖKL J., BÖHM R. 1953: Cutting of beef. (In Czech). SNTL, Praha, 47 p.

KOLDA J., BÖHM R., STẺRBA O. 1953: Cutting of beef. Cutting of pork. Cutting of veal. Six wall posters, MPP, Praha

KOLDA J., MLÁDEK F. 1951: Integumentum commune - Dermatology. (In Czech). SPN Praha, 108 p.

KRECHLER E. 1951: Contribution to the microscopic anatomy of the hairs of the horse. (In Czech). Thesis VSV Brno,

NAJBRT R. 1950: Fissility of the horse skin. (In Czech). Thesis VŠV Brno 
NAJBRT R., DOBES M. 1954: Contribution to cutting of hare. Acta Univ. Agric. Brno, B, 2(23):95-104.

NOVOTNYY E., BÖHM R. 1963: To the aiming of instructions in veterinary morphology. (In Czech). Veterinárství, 13: 282-283

PEJHOVSKÁ M. 1962: Summer and winter hairs of the Red Danish cattle. (In Czech). Thesis VŠV Brno

PLEVA V. 1951 : Argyrophilic fibrils in the skin. (In Czech). Thesis VŠV Brno

POSPIŠIL J. 1953 : Hairs of shepherd dogs. (In Czech). Thesis VŠV Brno

ROUBAL M. 953: Winter hairs of the horse. (In Czech). Thesis VŠV Brno

RƯŽIČKA J. 1948: Contribution to the histology of the kid skin (Capra hircus juv.). (In Czech). Thesis VŠV Brno STEINMETZ V. 1962: Hairs of calves from the different breeding conditions. (In Czech). Thesis VŠV Brno

SEVELA J. 1956: Contribution to the structure of dermis in cattle. (In Czech). Thesis VSV Brno

ŠTĚRBA O., BÖHM R. 1958: Cutting of mutton. Sborník CSAZV Živox̌ǐná výroba 3(31):153-156

TĚŚĹKOVA N. 1961 : Winter hairs of the cat. (In Czech). Thesis VŠV Brno

ZEMAN O. 1948: Contribution to the histology of the dog skin. (In Czech). Thesis VŠV Brno 